\title{
DOBUTAMINE STRESS ECHOCARDIOGRAPHY IN PATIENTS WITH DILATED CARDIOMYOPATHY
}

Vladimir Miloradovic and Milena Grubisa

Clinic of Cardiology, Clinical Center Kragujevac, Kragujevac, Serbia

\author{
DOBUTAMIN STRES EHOKARDIOGRAFIJA KOD BOLESNIKA SA \\ DILATACIONOM KARDIOMIOPATIJOM \\ Vladimir Miloradović i Milena Grubiša
}

Klinika za kardiologiju, Klinički centar Kragujevac, Kragujevac, Srbija

\begin{abstract}
A clear distinction between two of the most common forms of dilated cardiomyopathy is very important due to their different prediction and therapeutic approaches. Dobutamine stress echocardiography appears to be a noninvasive selection method due to its clear differentiation potential. Major factors influence test interpretation, resulting in a wide interval of diagnostic accuracy for this test. Fraction flow reserve (FFR) is a novel invasive method for estimating coronary artery stenosis responsible for myocardium ischaemia. Decisions about lesion significance in coronary blood vessels have thus far been based on angiographic estimations, but this approach is being replaced by FFR measurements, which serve as a new gold standard and involve a noninvasive test. The goal of this study was to clearly differentiate two forms of dilated cardiomyopathies through analysis of the segmented mobility of the left ventricular wall. Fifty patients were analysed: 20 with ischaemic dilated cardiomyopathy, which was confirmed not only through coronary angiography but also functionally through FFR measurement, and 30 patients with nonischaemic dilated cardiomyopathy, which was confirmed by coronary angiography. A standard dobutamine stress echocardiography protocol was implemented. A positive dobutamine stress echocardiography test was defined as the presence of emerging incidents in segment contractility or worsening of existing incidents in at least one segment. Statistically relevant differences in the movement dynamics of a number of differently characterised segments during the observed time intervals (ANOVA $p=0.000$ ) was noted in both groups of patients, as was variation in the index value of the summarized mobility of the left chamber wall. In patients with ischaemic cardiomyopathies, regional contractility worsened at the maximum dose of dobutamine; in contrast, this feature slightly improved in nonischaemic cardiomyopathy patients. The results indicate that by analysing segmental motion, these two forms of dilated cardiomyopathies can be differentiated with high sensitivity (Sn=90\%) and specificity (Sp=98\%), which can be interpreted as concrete evidence of truly ischaemic lesions in coronary blood vessels.
\end{abstract}

Keywords: dobutamine; echocardiography; cardiomyopathies; FFR

\section{SAŽETAK}

Jasno odvajanje dva najčešća oblika dilatacionih kardiomiopatija veoma je važno zbog različite prognoze $i$ terapijskog pristupa. Dobutamin stres ehokardiografija se čini neinvazivnom metodom izbora za njihovo jasno diferenciranje. Veliki uticaj operatera $i$ interpretaciji testa doveo je do širokog intervala dijagnostičke tačnosti ovog testa. Frakciona rezerva protoka (FFR) je nova invazivna metoda za procenu stenoze koronarnih arterija odgovornih za ishemiju miokarda. Odluka o značajnosti lezija na koronarnim krvnim sudovima na osnovu do sada neprikosnovene angiografske procene, zamenjena je FFR merenjem - novim zlatnim standardom prema kome se mogu tumačiti i rezultati do sada korišćenih neinvazivnih testova. Studija je imala za cilj da kroz analizu segmentne pokretliivosti zida leve komore napravi jasnu razliku izmedu ova dva oblika dilatacionih kardiomiopatija. Analizirano je 50 bolesnika od kojih 20 sa ishemijskom dilatacionom kardiomiopatijom što je dokazano ne samo angiografski već i funkcionalno, FFR merenjem. 30 bolesnika imalo je neishemijsku dilatacionu kardiomiopatiju, što je potvrdeno koronarografijom. Sproveden je standardni dobutamin stres ehokardiografski protokol. Pozitivan dobutamin stres ehokardiografski test je definisan kao pojava novonastalih ispada u segmentnoj kontraktilnosti, ili pogoršanje postojeće u najmanje jednom segmentu. Uočena je statistički značajna razlika u dinamici kretanja broja različito okarakterisanih segmenata, u posmatranim vremenima merenja (ANOVA p=0,000), kod obe grupe bolesnika, kao $i$ vrednosti indeksa zbirne pokretljivosti zida leve komore. U grupi sa ishemijskim kardiomiopatijama regionalna kontraktilnost se pogoršala na maksimalnoj dozi dobutamina, za razliku od neishemijskih kardiomiopatija, gde se blago poboljšala. Dobijeni rezultati ukazuju da se analizom segmentne pokretljivosti, mogu diferencirati ova dva oblika dilatacionih kardiomiopati$j a, i$ to sa visokom senzitivnošću $(S n=90 \%)$ i specifičnošću (Sp=98\%), što se može tumačiti pouzdanim dokazom o stvarno ishemijskim lezijama na koronarnim krvnim sudovima.

Ključne reči: dobutamin; ehokardiografija; kardiomiopatije, FFR 
ABBREVIATIONS

\author{
ANOVA - analysis of variance/analiza varijanse \\ Sp - specificity/specifičnost \\ Sn - sensitivity/senzitivnost \\ EDD - end-diastolic diameter/enddijastolni dijametar \\ EF - ejection fraction/ejekciona frkcija \\ LK - left chamber/leva komora \\ IM - myocardial infarction/infarkt miokarda
}

WMSI - wall motion score index/indeks zbira pokretljivosti zida DobAtro SET - dobutamin atropin stres ehokardiografski test SD - standard deviation/standardna devijacija

TP - true positives/stvarno pozitivna

TN - true negatives/stvarno negativna FP - false positives/lažno pozitivna

FN - false negatives/lažno negativna

\section{INTRODUCTION}

The ability of numerous non-invasive tests to detect coronary diseases of patients with dilated cardiomyopathy has been evaluated (1). Determining the presence of coronary disease in a patient is important not only for therapy but also for prognosis. Echocardiography is widely used in researching dilated cardiomyopathies. Unfortunately, regional fall-out of wall mobility in nonischaemic dilated cardiomyopathies and global dysfunction of patients with ischaemic cardiomyopathies frequently prevents the identification of coronary disease.

Several non-invasive techniques have been used to differentiate these two forms of dilated cardiomyopathy, but their differentiation has been limited due to numerous controversial results (2). The work of Shapr and associates was the first to demonstrate the higher sensitivity and specificity of dobutamine stress echocardiography test in patients with dilated cardiomyopathy (3). This report and the majority of studies (4) have been dominated by patients with ischaemic cardiomyopathy and data on myocardial infarction (MI). Few researchers have focused their work on segmented contractility in dobutamine stress echocardiography tests in patients with primary dilated cardiomyopathy $(3,5,6)$. Wide intervals of sensitivity, specificity and diagnostic accuracy can be generated due to inaccurate interpretations of coronary results. Interpreting angiographic stenosis from a $50 \%$ or even $75 \%$ lumen diameter as significant without functional assessment through FFR appears to be unacceptable today $(7,8)$. In our research, we have concluded that the normal response of the left chamber to an elevated dose of dobutamine in the absence of coronary disease is an increase in contractility. However, if significant coronary disease is present, contractility should initially increase after dobutamine infusion, and if the dose of dobutamine is high, contractility should significantly worsen due to a provocation of myocardium ischaemia. The goal of our study was to define a pattern for differentiating the most severe forms of dysfunction and dilatation of the left chamber (LC) of unknown cause during the dobutamine stress echocardiography test, based on characterisation of segmental contractility before and during dobutamine infusion in patients with ischaemic and nonischaemic (primary) dilated cardiomyopathy.

\section{MATERIAL AND METHODS}

During the period 2010-2012, the Clinic for Cardiology KC Kragujevac performed dobutamine stress echocardiography in 50 patients with dilated cardiomyopathy, with the addition of atropine in 15 patients. All patients were subjected to a coronary angiography procedure, and, for patients with stenosis

$>50 \%$, FFR measurements were performed. Significant stenosis was indicated by a measurement value $<0.80$.

Analysis of studied population. The study included patients with dilated cardiomyopathy without histories of myocardial infarction. To be included, patients needed to have the following: optimal ultrasound images, end-diastolic diameter (EDD) $\geq 6.0 \mathrm{~cm}$ (M-mode), ejection fraction (EF) $<40 \%$ (Simpson method). Patients were excluded based on the existence or a history of the following: congestive heart failure, unstable angina, significant ventricular arrhythmias, LV aneurysm, severe valvular disease appliances and any contraindications to dobutamine infusion or the administration of atropine (7).

DobAtro SET protocol. The protocols for DobAtro SET vary depending on the facility in which the test is performed, with differences in the dobutamine dose (20-40 $\mathrm{mg} / \mathrm{kg} / \mathrm{min})$, atropine dose $(0-2 \mathrm{mg})$ and administration time of various dobutamine doses (2-8 $\mathrm{min})$. The most widely used protocol for DobAtro SET, which is applied in our practice and was used in this work, include the following: after a baseline echocardiographic study, dobutamine is administered intravenously at an initial dose of $5 \mu \mathrm{g} / \mathrm{kg} /$ min for 3 minutes and is then increased to $10 \mu \mathrm{g} / \mathrm{kg} / \mathrm{min}$, $20 \mu \mathrm{g} / \mathrm{kg} / \mathrm{min}, 30 \mu \mathrm{g} / \mathrm{kg} / \mathrm{min}$, and up to a maximum of 40 $\mathrm{mg} / \mathrm{kg} / \mathrm{min}$ over three minute intervals at each dose. If the submaximal frequency was not achieved (calculated by the formulas 220 - age $\mathrm{x} 0.85$ for men and 200 - age $\mathrm{x} 0.85$ for women), we administered atropine at a dose of $0.25 \mathrm{mg}$ to a maximum dose of $2 \mathrm{mg}$. Patient echocardiograms were continuously monitored, and the results were recorded on three-channel electrocardiograph devices after the end of each dobutamine dosing interval and 6 min after the test. The echocardiograms were continuously monitored by videotape recordings of the final minute of each stage and 5 min after the test. Longitudinal and transverse sections of the parasternal view and the apical view with four or 
two cavities were recorded. The echocardiographic studies were performed on an ultrasonic device Vivid 7 GE3.5 $\mathrm{MHz}$ and recorded in AVI format on CDs. Each stage of the test was digitised directly (online) with four sections using the digitalising system NovaMicrosonics.

Interpretation of echocardiographic results. Segmental myocardial contractility was assessed according to the recommendations of the American Society of Echocardiography, based on which the left ventricle is divided into 16 segments. The left ventricular wall motion sum index (WMSI) was calculated for each stage of the test by adding together the points of each segment. The contractility of each segment was determined semiquantitatively by scoring from 1 to 4, wherein normal contractility is assessed as 1 (> $5 \mathrm{~mm}$ endocardial movement), hypokinesia as 2 (> 5 $\mathrm{mm}$ endocardial movement), akinesia as 3 (lack of movement or endocardial movement $<2 \mathrm{~mm}$ ) and dyskinesia as 4 (paradoxical outward movement in systole). A negative DobAtro SET was defined as uniformly increasing mobility of walls and systolic thickening with telesystolic reduction of the left ventricular volume. A positive DobAtro SET was defined as the occurrence of failure emerging in segmental contractility or worsening failure in at least one segment. Reading of the results was performed by two independent echocardiographers who were not familiar with the coronary angiographic findings.

Stress electrocardiography. Before the test, and after each stage of the test, electrocardiographic recordings were made on a three-channel electrocardiograph. The EKGs were interpreted as normal, ischaemic or non-diagnostic. Ischaemic changes were defined by the presence of ST segment depression $>0.1 \mathrm{mV}$ or $>0.2 \mathrm{mV}$ in the leads, with ST abnormalities at rest. The electrocardiograms were interpreted as non-diagnostic if blockage of the left branches was present after digitalis therapy or ST depression $>2 \mathrm{~mm}$ was observed at rest.

Coronary angiography. Visual assessment of stenosis diameter expressed in \% was performed by two experienced angiographists. Significant coronary stenosis with a $>50 \%$ reduction in the absolute lumen diameter of the main epicardial arteries or their main branches was the indication for FFR measurements. A measured FFR value < 0.80 indicated the presence of significant coronary stenosis. Patients with verified significant contraction of 1 main coronary artery were considered to have ischaemic dilated cardiomyopathy.

Statistic data analysis. The following descriptive statistics methods were used to describe the general characteristics of patients in the observed group: absolute numbers and proportions, central tendency measures (average value) and variability measures (standard deviation). Student's t-tests were used to compare the average observed numeric values between two groups. When a characteristic's distribution prevented the application of parametric statistics, a Mann-Whitney test was used. Two-factor variance analysis was used to compare the average number of segments for certain categories of wall mobility between the two groups in every observation period. Based on the test results and given diagnosis, test sensitivity and specificity were determined, as were positive and negative predictive values.

\section{RESULTS}

Clinical, electrocardiographical and basic echocardiographical data. The data obtained for the tested groups are shown in Table 1 . No statistically significant differences in the anthropometric values, echocardiographical or echocardiographical data were observed between groups. A statistically considerably higher frequency of angina pectoris was observed in patients with ischaemic cardiomyopathy. Smoking and inheritance were the dominant risk factors in the ischaemic and nonischaemic dilated cardiomyopathy groups, respectively.

Results of the stress test and side effects. When comparing patients with ischaemic and nonischaemic dilated cardiomyopathy, no statistically significant differences were found in the average dobutamine dose, atropine dose, achieved submaximal frequency, systolic blood pressure or double product. We also did not observe any considerable differences in the appearance of chest pain, dyspnoea or ST segment modifications. Chest pain was registered in 4 and 3 patients with ischaemic and nonischaemic dilated cardiomyopathy, respectively. Dyspnoea was reported in 3 patients with nonischaemic dilated cardiomyopathy, compared to 2 patients in the other group. Modifications in the ST segment were not observed in nonischaemic dilated cardiomyopathy patients but were found in 2 patients from the first group (Table 2).

Results of echocardiographic monitoring of LK wall mobility. The segment LK classification results were tested using two-factor and repeated measures variance analysis at rest, after a low dose of dobutamine, and after the dobutamine dosing tests. Analysis was performed separately for the ischaemic and nonischaemic dilated cardiomyopathy groups (Table 3). In both tested groups, the LK function was significantly reduced. Regional dyssynergy was significantly dilated in both groups. After a low dose of dobutamine, contractility was improved in both tested groups, with an increasing of number of segments identified as normokinetic versus segments with problematic kinetics. With a high dose of dobutamine, an evident increase in the number of segments with irregular kinetics was observed in patients with ischaemic dilated cardiomyopathy, whereas individuals from the other group exhibited further increases in the number of segments with normal kinetics. In regards to segment movement dynamics, an intergroup analysis (Bonferroni t-test) indicated a lack of statistically significant differences in the average number of normal segments between tested groups $(\mathrm{p}=0.084)$. Additionally, no distinction between these two groups in terms of the average number of normal segments was found after a low dobutamine dose treatment $(\mathrm{p}=0.067)$. At peak do- 
Table 1. Clinical, electrocardiographic and baseline echocardiographic data

\begin{tabular}{|c|c|c|c|c|}
\hline \multicolumn{2}{|c|}{ Observed parameters } & Ischemic heart disease & Cardiomyopathies & $\begin{array}{l}\text { Differentiation signifi- } \\
\text { cance }\end{array}$ \\
\hline \multicolumn{2}{|c|}{$\begin{array}{l}\text { Average age }\left(\mathrm{X}_{ \pm} \mathrm{SD}\right) \\
\text { (in years) }\end{array}$} & $55.3 \pm 8.54$ & $50.33 \pm 10.56$ & Not significant \\
\hline \multicolumn{2}{|c|}{$\begin{array}{l}\text { Wight }\left(\mathrm{X}_{ \pm} \mathrm{SD}\right) \\
\text { (in kilograms) }\end{array}$} & $78.95 \pm 9.04$ & $83.47 \pm 15.22$ & Not significant \\
\hline \multicolumn{2}{|c|}{$\begin{array}{l}\text { Height }\left(\mathrm{X}_{ \pm} \mathrm{SD}\right) \\
\quad(\text { in } \mathrm{cm})\end{array}$} & $172.05 \pm 6.85$ & $175.17 \pm 7.49$ & Not significant \\
\hline \multicolumn{2}{|l|}{ BMI } & $26.75 \pm 2.70$ & $27.27 \pm 4.17$ & Not significant \\
\hline \multirow{2}{*}{$\begin{array}{c}\text { Sex } \\
(\mathbf{n}(\%))\end{array}$} & male & $20(100 \%)$ & $25(83.3 \%)$ & \multirow{2}{*}{ Not significant } \\
\hline & female & $0(0 \%)$ & $5(16.7 \%)$ & \\
\hline \multirow{4}{*}{$\begin{array}{l}\text { NYHA } \\
(\mathbf{n}(\%))\end{array}$} & class I & $1(5 \%)$ & $2(6.7 \%)$ & \multirow{4}{*}{ Not significant } \\
\hline & ccass II & $14(70 \%)$ & $13(43.3 \%)$ & \\
\hline & class III & $5(25 \%)$ & $14(46.7 \%)$ & \\
\hline & class IV & $0(0 \%)$ & $1(3.3 \%)$ & \\
\hline \multirow{2}{*}{$\begin{array}{c}\text { Angina } \\
(\mathbf{n}(\%))\end{array}$} & yes & $12(60 \%)$ & $8(26.7 \%)$ & \multirow{2}{*}{ Significant } \\
\hline & no & $8(40 \%)$ & $22(73.3 \%)$ & \\
\hline \multirow{2}{*}{$\begin{array}{l}\text { Hypertension } \\
(\mathbf{n}(\%))\end{array}$} & yes & $10(50 \%)$ & $12(40 \%)$ & \multirow{2}{*}{ Not significant } \\
\hline & no & $10(50 \%)$ & $18(60 \%)$ & \\
\hline \multirow{2}{*}{$\begin{array}{l}\text { Diabetes mellitus } \\
\qquad(\mathbf{n}(\%))\end{array}$} & yes & $4(20 \%)$ & $4 .(13.3 \%)$ & \multirow{2}{*}{ Not significant } \\
\hline & no & $16(80 \%)$ & $26(86.7 \%)$ & \\
\hline \multirow{2}{*}{$\begin{array}{l}\text { Left bandle branch block } \\
\qquad(\mathbf{n}(\%))\end{array}$} & yes & $4(20 \%)$ & $9(30 \%)$ & \multirow{2}{*}{ Not significant } \\
\hline & no & $16(80 \%)$ & $21(70 \%)$ & \\
\hline \multicolumn{2}{|c|}{ Ejection fraction } & $21.85 \pm 5.77$ & $20.13 \pm 4.94$ & Not significant \\
\hline \multicolumn{2}{|c|}{ End diastolic dijameter EDD $(\mathrm{mm})$} & $67.10 \pm 4.13$ & $70.80 \pm 5.83$ & Significant \\
\hline \multirow{2}{*}{$\begin{array}{c}\text { Mitral regrgitation } \\
(\mathbf{n}(\%))\end{array}$} & yes & $10(50 \%)$ & $16(53.3 \%)$ & \multirow{2}{*}{ Not significant } \\
\hline & no & $10(50 \%)$ & $14(46.7 \%)$ & \\
\hline \multirow{2}{*}{$\begin{array}{l}\text { Family history of disease } \\
\qquad(\mathbf{n}(\%))\end{array}$} & yes & $4(20 \%)$ & $15(50 \%)$ & \multirow{2}{*}{ Significant } \\
\hline & no & $16(80 \%)$ & $15(50 \%)$ & \\
\hline \multirow{2}{*}{$\begin{array}{c}\text { Smoking } \\
(\mathbf{n}(\%))\end{array}$} & yes & $15(75 \%)$ & $12(40 \%)$ & \multirow{2}{*}{ Significant } \\
\hline & no & $5(25 \%)$ & $18(60 \%)$ & \\
\hline \multirow{2}{*}{$\begin{array}{l}\text { Hypercholesterolemia } \\
\text { (n (\%)) }\end{array}$} & yes & $2(10 \%)$ & $0(\%)$ & \multirow{2}{*}{ Not significant } \\
\hline & no & $18(90 \%)$ & $30(100 \%)$ & \\
\hline \multirow{2}{*}{$\begin{array}{c}\text { Atrial fibrillation } \\
(\mathbf{n}(\%)) \\
\end{array}$} & yes & $6(30 \%)$ & $6(20 \%)$ & \multirow{2}{*}{ Not significant } \\
\hline & no & $14(70 \%)$ & $24(80 \%)$ & \\
\hline \multirow{2}{*}{$\begin{array}{c}\text { Sinus rhythm } \\
(\mathrm{n}(\%))\end{array}$} & yes & $14(70 \%)$ & $24(80 \%)$ & Not cirnificant \\
\hline & no & $6(30 \%)$ & $6(20 \%)$ & 190 sighitite dite \\
\hline
\end{tabular}

butamine doses $(\mathrm{p}=0.008)$ and after testing $(\mathrm{p}=0.039)$, statistically significant differences in the average number of normal segments were observed between patients with ischaemic and nonischaemic dilated cardiomyopathy. The average number of hypokinetic segments differed at statistically significant levels between the 2 tested patient groups at rest $(\mathrm{p}=0.03)$ and after testing $(\mathrm{p}=0.018)$, whereas, at low $(\mathrm{p}=0.0114)$ and peak dobutamine doses $(\mathrm{p}=0.505)$, so such differences were observed in the number of hypokinetic segments. For akinetic segments, significant differences in the average number of relevant segments were found at only peak doses of dobutamine $(\mathrm{p}=0.048)$.
LK wall collective mobility index (WMSI) values. The WMSI values were monitored for the two groups of patients at rest and after a low dose of dobutamine, peak dobutamine dose, and completion of testing. Two-factor repeated measures analysis of variance was used to compare the obtained index values. Variation in the WMSI values in this study resulted from differences in heart disease derivation, so we analysed the WMSI measurement time (at rest, at low doses of dobutamine, at peak dobutamine doses and after the test) and individual differences between patients. In this model, the measurement time was used as an intrasubject factor, and the difference be- 
tween ischaemic and nonischaemic dilated cardiomyopathy patients served as an intersubject factors. This analysis indicated a difference in the observed measurement times and in the dynamics of changes in WMSI values between observed groups at given measurement times. Significant differences were observed in the dynamic movement value of the calculated WMSI values, which were obtained by measuring parameters of wall mobility segment analysis before, during and after the test, between the two patient groups at given measurement times (two-way repeated measures ANOVA, measuring time "patients group; $p=0.000$ ). Differences between the WMSI average values were observed at various measurement times (two-way repeated measures ANOVA, measuring time; $\mathrm{p}=0.000$ ) (Table 4 , Graph 1 ). After an almost uniform change in the WMSI after a low dobutamine dose, the high dose of dobutamine provoked ischaemia in and worsened the kinetics of the group with ischaemic dilated cardiomyopathy. After the test, WMSI values were registered. We divided our patients into four groups ac-

Table 2. Stress test results and side effects

\begin{tabular}{|c|c|c|c|c|}
\hline \multicolumn{2}{|c|}{ Observed parameters } & Ischemic heart disease & Cardiomyopathies & $\begin{array}{l}\text { Differentiation signifi- } \\
\text { cance }\end{array}$ \\
\hline \multicolumn{2}{|c|}{$\begin{array}{l}\text { Average doses of dobutamine }\left(\mathrm{X}_{ \pm} \mathrm{SD}\right)(\mathrm{u} \mu \mathrm{g} / \\
\mathrm{kg} / \mathrm{min})\end{array}$} & $37.5 \pm 5.5$ & $37.33 \pm 4.5$ & Not significant \\
\hline \multicolumn{2}{|l|}{$\begin{array}{l}\text { Average doses of atropine } \\
\left(\mathrm{X}_{ \pm} \mathrm{SD}\right)(\mathrm{u} \mathrm{mg})\end{array}$} & $0.53 \pm 0.21$ & $0.5 \pm 0.2$ & Not significant \\
\hline \multirow{2}{*}{$\begin{array}{l}\text { Atropine } \\
(\mathbf{n}(\%))\end{array}$} & yes & $8(40 \%)$ & $7(23.3 \%)$ & \multirow{2}{*}{ Not significant } \\
\hline & no & $12(60 \%)$ & $23(76.7 \%)$ & \\
\hline \multirow{2}{*}{$\begin{array}{l}\text { Achieved maximal frequency } \\
\qquad(\mathrm{n}(\%))\end{array}$} & yes & $16(80 \%)$ & $23(73.3 \%)$ & \multirow{2}{*}{ Not significant } \\
\hline & no & $4(20 \%)$ & $7(26.7 \%)$ & \\
\hline \multicolumn{2}{|c|}{ Maximal frequency $\left(\mathrm{X}_{\underline{+}} \mathrm{SD}\right)$} & $128.53 \pm 23.94$ & $137.85 \pm 22.24$ & Not significant \\
\hline \multicolumn{2}{|c|}{ Maximal values od systolic pressure $\left(\mathrm{X}_{\underline{+}} \mathrm{SD}\right)$} & $132.83 \pm 21.72$ & $143 \pm 13.8$ & Not significant \\
\hline \multicolumn{2}{|c|}{ Frequency x systolic pressure/1000 } & $17.29 \pm 5.1$ & $19.78 \pm 3.61$ & Not significant \\
\hline \multirow{2}{*}{$\begin{array}{c}\text { Chest pain } \\
\text { (n (\%)) }\end{array}$} & yes & $4(20 \%)$ & $3(10 \%)$ & \multirow{2}{*}{ Not significant } \\
\hline & no & $16(80 \%)$ & $27(90 \%)$ & \\
\hline \multirow{2}{*}{$\begin{array}{c}\text { Dispnea } \\
(\mathbf{n}(\%))\end{array}$} & yes & $3(15 \%)$ & $2(6.7 \%)$ & \multirow{2}{*}{ Not significant } \\
\hline & no & $17(75 \%)$ & $28(93.3 \%)$ & \\
\hline \multirow{2}{*}{$\begin{array}{l}\text { ST segment changes } \\
\text { (n (\%)) }\end{array}$} & yes & $2(10 \%)$ & $0(0 \%)$ & \multirow{2}{*}{ Not significant } \\
\hline & no & $18(90 \%)$ & $30(100 \%)$ & \\
\hline
\end{tabular}

Table 3. Grading of left ventricular segments at stress test

\begin{tabular}{|c|c|c|c|c|c|}
\hline \multicolumn{2}{|c|}{ Observed parameters } & \multicolumn{4}{|c|}{ Measuring time } \\
\hline & Base & $\begin{array}{c}\text { Low dose of dobu- } \\
\text { tamine }\end{array}$ & $\begin{array}{l}\text { Peak dose of dobu- } \\
\text { tamine }\end{array}$ & Rest & \\
\hline \multirow{3}{*}{ 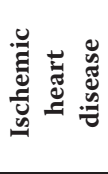 } & Normal segments & $4.25 \pm 4.04$ & $6.1 \pm 3.85$ & $3.55 \pm 3.5$ & $4.05 \pm 3.78$ \\
\hline & $\begin{array}{c}\text { Hypokinetics seg- } \\
\text { ments }\end{array}$ & $9.25 \pm 4.68$ & $7.65 \pm 3.91$ & $8.05 \pm 3.82$ & $9.25 \pm 3.74$ \\
\hline & Akinetics segments & $2.8 \pm 2.17$ & $2.15 \pm 1.95$ & $4.4 \pm 3.15$ & $2.7 \pm 2.18$ \\
\hline \multirow{3}{*}{ 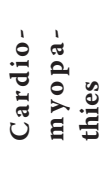 } & Normal segments & $1.33 \pm 1.88$ & $4.27 \pm 3.05$ & $6.07 \pm 2.91$ & $1.7 \pm 2.31$ \\
\hline & $\begin{array}{c}\text { Hypokinetics seg- } \\
\text { ments }\end{array}$ & $11.7 \pm 3.09$ & $9.37 \pm 3.55$ & $7.3 \pm 3.9$ & $11.67 \pm 3.18$ \\
\hline & Akinetics segments & $2.97 \pm 3.06$ & $2.83 \pm 2.96$ & $2.63 \pm 2.85$ & $2.83 \pm 3.01$ \\
\hline
\end{tabular}

Table 4. The value of WMSI at patients with ischemic and nonischemic cardiomyopathy

\begin{tabular}{|c|c|c|c|c|}
\hline \multirow{2}{*}{ Posmatrane grupe ispitanika } & \multicolumn{3}{|c|}{ Vrednosti WMSI u posmatranim vremenima merenja (X+SD) } \\
\cline { 2 - 6 } & Base & $\begin{array}{c}\text { Low dose of dobu- } \\
\text { tamine }\end{array}$ & $\begin{array}{c}\text { Peak dose of dobu- } \\
\text { tamine }\end{array}$ & \multicolumn{2}{|c|}{ Rest } \\
\hline Ischemic heart disease & $1.91_{ \pm} 0.3$ & $1.74 \pm 0.29$ & $1.79 \pm 0.28$ & $1.91 \pm 0.31$ \\
\hline Cardiomyopathies & $2.1 \pm 0.25$ & $1.93 \pm 0.26$ & $2.06 \pm 0.28$ \\
\hline
\end{tabular}




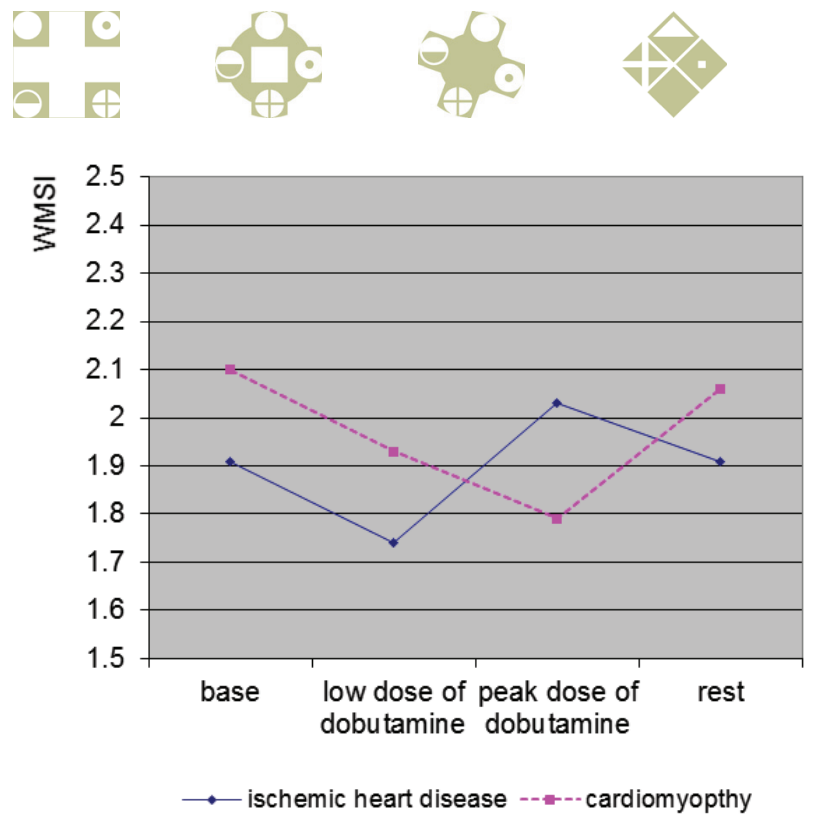

Graph 1. WMSI at the patients with ischemic and nonischemic dilated cardiomyopathy

cording to their stress test results: group 1 for truly positive results (ischaemic heart disease and positive test, TPtrue positives), group 2 for truly negative results (patients with nonischaemic dilated cardiomyopathy and negative test, TN-true negatives), group 3 for false positive results (nonischaemic dilated cardiomyopathy and positive test, FP-false positives) and group 4 for false negative results (ischaemic heart disease and negative test, FN-false negatives). After creating $2 \times 2$ contingency tables, we calculated the following rates: $\mathrm{TPR}=\mathrm{TP} / \mathrm{TP}+\mathrm{FN}$ and $\mathrm{TNR}=\mathrm{TN} /$ TN+FP. Sensitivity and specificity are widely accepted synonyms for TPR and TNR. Test sensitivity is an indicator of the test's ability to detect patients with ischaemic disease; in our case, the test sensitivity was $90 \%$ (CI=85$100 \%)$. Test specificity, which reflects the test's ability to identify healthy patients, was 98\% (CI=96\%-100\%).

\section{DISCUSSION}

Differentiating between ischaemic and nonischaemic dilated cardiomyopathy is highly important $(10,11,12,13)$, but the clinical aspect of these conditions can be very complicated. Ischaemia is likely the cause of cardiomyopathy in patients with myocardium infarct (IM) or aneurism LK. Nevertheless, some patients with ischaemic cardiomyopathy do not exhibit anamnestic or electrocardiographic signs of IM nor anamnestic data indicating chest pain but demonstrate more diffuse rather than regional hypocontractility of segments in ultrasound $(14,15)$. In contrast, many patients with nonischaemic dilated cardiomyopathy often experience angina pain, and these patients' electrocardiograms contain features that match the signs of IM (11). The main advantage of our research is the absolute confirmation of ischaemia in patients with dilated cardiomyopathy by FFR measurements, compared with other research that used only coronary graph results as an indicator of ischaemic disease aetiology, without reliable confirmation about the existence of ischaemia $(7,8)$. In our research, we clearly demonstrated that in patients with LK dysfunction of unknown cause, regional dyssynergy upon receiving a peak dose of dobutamine clearly indicates an ischaemic aetiology of disease. In a carefully chosen group of patients, we confirmed that dobutamine stress echocardiography can differentiate two forms of dilated cardiomyopathies. We noticed that for nonischaemic dilated cardiomyopathies, contractility responses to dobutamine were not characterised by global hyperkinesia but rather mild and moderate improvements in contractility, which often limited to partial LK segments. Currently, other techniques are used to differentiate these two forms of dilated cardiomyopathies such as talium-201 scintigraphy at rest. However, loading and infusion of dipyridamole does not offer final solutions, whereas the use of positron emission tomography is limited by its price. New techniques and myocardium acquisition have not solved the problem of low applicability thus far $(16,17)$. The interpretation of dyssynergy at rest is a well-known technique, due to infarct scarring, but often these large or real aneurysms can be caused by myocarditis. Mild to moderate dyssynergy is commonly observed with nonischaemic dilated cardiomyopathies and can be caused by hypoperfusion as a result of inadequate microcirculation $(18,19,20)$. In our study, basal hypocontractility in the ischaemic dilated cardiomyopathy group was less homogeneous than in the other group. In our research, we did not clearly separate necrotic myocardium from mixed myocardium, according to patient responses to dobutamine.

Electrocardiographic and haemodynamic data were not useful in our study for differentiating the two forms of cardiomyopathy. The response to a low dose of dobutamine was similar in both groups due to a favourable response from the largest number of hypokinetic segments. Nevertheless, this improvement in ischaemic cardiomyopathy spread to certain akinetic segments, which probably were part of the hibernating myocardium, whereas other segments remained dyssynergic. For a high dose of dobutamine in nonischaemic dilated cardiomyopathy patients, hypo- and akinetic segments maintained their previous improvement in kinetics, compared with the ischaemic disease group that exhibited a worsening in kinetics, with and without the presence of previous dyssynergy. The WMSI values also differed between tested groups at high doses of dobutamine, which was previously reported by Sharp et al. and Vign et al. $(21,3,6)$. In contrast to the aforementioned studies, we registered a significant increase in the WMSI when increasing from a low to high dose of dobutamine, with an especially effectual response in the nonischaemic dilated cardiomyopathy group, whereas the ischaemic diseases group exhibited different responses. Variations in the tested groups and different dobutamine infusion protocols (dobutamine dose, duration of each stage) can partially 
explain these discrepancies. In some undefined cases, intertwined factors of both forms of cardiomyopathies can be assumed to be responsible for false negative and false positive results $(22,23)$. Extensive collaterals and inability to achieve adequate loads for this group of patients can explain the decreased test sensitivity. Patients with nonischaemic diseases often exhibit weak and limited responses in certain segments during dobutamine infusion. Registering a worsening of LK function for a high dose of dobutamine in the absence of coronary disease is likely the effect of the progressive phase of the myopathic process or simply a decreased coronary reserve $(24,25,26)$.

Limitations during the research. This study included several limitations. The number of patients was relatively small. We did not use relatively new technical modalities to improve endocardium visualisation. We did not consider right ventricle reactions to the infusion of dobutamine or right ventricle dimensions, based on the opinion that the left ventricle's function is preserved in ischaemic but not in nonischaemic dilated cardiomyopathies. The aetiology of dilated cardiomyopathy in single vessel coronary disease is disputable, as is the interpretation of results in these cases.

\section{CONCLUSION}

Dobutamine-atropine stress echocardiography is a comfortable patient testing method with very mild and rare side effects. The dynamics of LV segments in patients with ischaemic dilated cardiomyopathy exhibited significant differences during the individual stages of the test as a consequence of the test's ability to provoke ischaemia. The dynamics of LV segments in patients with nonischaemic (primary) dilated cardiomyopathy reflects the positive inotropic effect of dobutamine in healthy coronary vessels. Changes in the WMSI value during the test are a clear predictor of ischaemic heart disease in patients with severe LV dysfunction of unknown origin. The sensitivity of the test was $90 \%$, and the specificity of the test was $98 \%$, with the identification of actual ischaemic lesions in coronary blood vessels confirmed by FFR measurement.

Finally, patients with severe LV dysfunction are all different, and the possibility of coronary artery disease in patients with primary dilated cardiomyopathy should be noted.

\section{LITERATURE}

1. Marwick TH. The effect of coronary occlusion on myocardial contraction. In : Marwick TH, editor. Stres echocardiography 1th ed. Netherlands: Kluwer; 1994.

2. Marwick TH. Stress echocardiography. In: Topol EJ, editor. Texbook of Cardiovascular Medicine 2th ed. Philadelphia: Lippincott-Raven; 1998.
3. Sharp SM, Sawada SG, Segar DS, Ryan T, Kovasc R, Fineberg NS et al. Dobutamine stress echocardiography: Detection of coronary Artery disease in patients with dilated cardiomyopathy. J Am Cardiol 1994; 24:934-9.

4. Sawada SG, Segar DS, Ryan T, Brown SE, Dohan AM, Williams R et al. Echocardiographic detection of coronary artery disease during dobutamin infusion Circulation 1991; 83:1605-14.

5. La Canna G, Alfieri O, Giubbini R, Gargano M, Ferrari R, Visioli O. Echocardiography during infusion of dobutamine for identification of reversible dysfunction in patients with chronic coronary artery disease. J Am Coll Cardiol 1994; 23:617-26.

6. Vigna C, Russo A, De Rito V, Perna GP, Tsta M, Lombardo A et al. Regional wall moton analysis by dobutamine echocardiography to distinguish between ischemic amd nonischemic dilated cardiomyopathy. Am Heart J 1996; 131:537-43.

7. Pim A L, Tonino M, Bernard De Bruyne, Nico H J Pijls, Uwe S, Fumiaki I, Marcel van 't Veer et al. Fractional Flow Reserve versus Angiography for Guiding Percutaneous Coronary Intervention. N Engl J Med 2009; 360:213-24.

8. Bernard De Bruyne, Nico H J Pijls, Bindu K, Emanuele B, Pim A L T, Zsolt P et al. Fractional Flow ReserveGuided PCI versus Medical Therapy in Stable Coronary Disease. N Engl J Med 2012; 367:991-1001

9. Miloradović V, Otašević P, Bojić D, Popović AD. Klinički značaj dobutamin stres ehokardiografije. Ultrazvuk 1997; 5:11-17.

10. Franciosa JA, Wilen MV, Ziesche S, Cohn J. Survival in man with severe chronic left ventricular failure due to coronary artery disease or idiopatic dilated cardiomyopathy. Am J Cardiol 1983; 51:831-7.

11. Kruti J, Irshad A, Emily R, Irmina G P, Jothiharan M, Masoor K, Harvey F and Sawada S. Effect of improvement in left ventricular ejection fraction on long-term survival in revascularized patients with ischaemic left ventricular systolic dysfunction. European Journal of Echocardiography (2011) 12, 454-60.

12. Poldermans D, Elhendy A, Harvey F and Sawada S. Prognosis of patients with ischaemic cardiomyopathy after coronary revascularisation: relation to viability and improvement in left ventricular ejection fraction. Heart 2009;95:1273-77.

13. V Rizzello V, Poldermans D, Schinkel A F L, Biagini E, Boersma E, Elhendy A, Sozzi F B, Maat A, Crea F, Roelandt J R T C, Bax J. Long term prognostic value of myocardial viability and ischaemia during dobutamine stress echocardiography in patients with ischaemic cardiomyopathy undergoing coronary revascularisation. Heart 2006;92:239-244.

14. Medina R, Panidis IP, Morganroth J, Kotler MN, Mintz GS. The value of echocardiographic regional wall motion abnormalities in detecting coronary artery disease in patients with and without a dilated left ventricle. Am Heart J 1985; 109:799-803. 
15. Rogel VL, Pellikka PA, Oh JK, Baily KR, Tajik AJ. Identification of multivassel coronary artery disease by exercise echocardiography. J Am Coll Cardiol 1994; 24:109-14.

16. Elhendy A, Van Donburg RT, Bax JJ, Poldermans D, Nierop PR, Geleijnse ML, Roelandt JR. The grade of worsering of regional function during dobutamine stress echocardiography predicts the extent of myocardial perfusion abnormalites. Heart 2000; 83:35-39.

17. Kramer CM, Malkowski MJ, Mankad S, Theobald TM, Paksitis DL, Rogers WJ. Magnetic resonance tagging and echocardiographic response to dobutamine and functional improvement after reperfused myocardial infarction. Am Heart J 2002; 143:1046-51.

18. Diaz RA, nihoyannopoulos P, Athanassopoulos G, Oakley CM. Usefulness of echocardiography to diferentiate dilated cardiomyopathy. Am J Cardiol 1994;68:1224'7.

19. Krahwinkel W, Ketteler T, Godke J. Dobutamine stres echocardiography. Eur Heart J 1997; 18( Suppl D):D9-15.

20. Pratali L, Picano E, Otašević P, Vigna V, Palinkas A, Cortigiani L et al. Prognostic significance of the dobutamine echocardiography test in idiopatic dilated cardiomyopathy. Am J cardiol 2001; 88:1374-8.

21. Jeane M T, Abdou E, James R A, Feng X, Anna C M and Thomas R P. Prognostic Value of Dobutamine Stress
Myocardial Contrast Perfusion Echocardiography. Circulation. 2005;112:1444-50.

22. Squeri A, Gaibazzi N, Reverberi C, Caracciolo MM, Ardissino D and Gherli T. Ejection fraction change and coronary artery disease severity: a vasodilator contrast stress-echocardiography study. J Am Soc Echocardiogr. 2012 Apr;25(4):454-9.

23. Panza J M, Laurienzo J M, Quyyumi A A and Dilsizian V. Relation Between Ischemic Threshold Measured During Dobutamine Stress Echocardiography and Known Indices of Poor Prognosis in Patients With Coronary Artery Disease. Am Heart J 1995; 122: 893-99.

24. Picano E. Stress echocardiography. Springer-Verlag Berlin, Heidelberg. 2009.

25. Douglas SP, Khandheria B, Stainback FR et al. ACCF/ ASE/ACEP/AHA/ASNS/SCAI/SCCT/SCMR 2008, Approprietnes criteria for stress echocardiography. J Am Coll Cardiol 2008;51:1127-47.

26. Ghani A \& J-H. E. Dambrink \& A. W. J. van 't Hof \& J. P. Ottervanger \& A. T. M. Gosselink \& J. C. A. Hoorntje. Treatment of non-culprit lesions detected during primary PCI: long-term follow-up of a randomised clinical trial. Neth Heart J (2012) 20:347-353 